\title{
Effects of a structured educational intervention on metabolic control of type- 1 diabetes mellitus patients
}

\author{
Bernie Endyarni, Jose RL Batubara, I Boediman
}

\begin{abstract}
Background Children with type-1 diabetes face not only shortterm complications but also long-term microvascular and macrovascular complications. Therefore, a continuing medical care and education to reach blood glucose near normal range is absolutely required. An addition of behavioral educational intervention to intensive diabetes management resulted in improved metabolic control and quality of life.

Objective To determine the effects of a structured educational intervention to parents and patients with type- 1 diabetes mellitus on their knowledge and patient metabolic control.

Methods In this interventional study with pretest-posttest design at Department of Child Health, Medical School, University of Indonesia, a total of 21 patients with the age between 8 and 18 years and their parents were assigned to follow a structured educational program over period of 6 months. During the 6 intervention sessions, some procedures were applied: obtaining $\mathrm{HbA} 1 \mathrm{c}$ at initial, $3^{\text {rd }}$ and $6^{\text {th }}$ month using HPLC procedure, classroom teaching program, small group discussions, role-playing and pre-posttests.

Results The mean $\mathrm{HbA} 1 \mathrm{c}$ level in the 21 children and adolescents at initial, $3^{\text {rd }}$ and $6^{\text {th }}$ month were $10.05 \%$ (SD 2.67\%), 10.28\% (SD 2.23\%) and $10.01 \%$ (SD 2.67\%), which showed no significant changes $(P>0.05)$. After 6 educational sessions, the result showed significant changes in both parents' $(P<0.05)$ and patients' knowledge $(P<0.05)$. Patients' diabetes-related knowledge had a moderate correlation $(r=-0.632 ; P=0.02)$, but parents' diabetes-related knowledge had no significant correlation $(r=-0.348 ; P=0.122)$ with patient mean $\mathrm{HbA} 1 \mathrm{c}$ level.

Conclusion A structured educational intervention used in this study is able to improve parents' and patients' diabetes-related knowledge significantly. Patients' diabetes-related knowledge had a significant correlation with metabolic control [Paediatr Indones 2006;46:260-265].
\end{abstract}

Keywords: type-1 diabetes, HbAlc, metabolic control, education. he most common type of diabetes mellitus
children is type-1 diabetes. It is
characterized by hyperglycemia resulting
from autoimmune destruction of the â-cell of the pancreas with consequent or absolute insulin deficiency. ${ }^{1-5}$ There is a wide variation in incidence of type-1 diabetes among population groups with the highest incidence appears in Scandinavian countries. ${ }^{2-}$ ${ }^{4}$ Unfortunately, data regarding this incidence in Indonesia is not available. ${ }^{3,4,6}$ Batubara ${ }^{6}$ reported that the majority (93\%) of the 69 patients from 7 pediatric diabetes centers in Indonesia were type-1 diabetes. The incidence rate at Endocrinology Clinic, Department of Child Health, Medical School, University of Indonesia (1989-1998) was 0.028\%.?

Children with type-1 diabetes face not only short-term complications such as hypoglycemia and diabetic ketoacidosis (DKA), ${ }^{1-5,8}$ but also long-term microvascular and macrovascular complications. ${ }^{1-5,9}$ therefore a continuing medical care and education to reach blood glucose near normal range is absolutely required. ${ }^{9-11}$ The level of HbA1c has become the

From the Department of Child Health, Medical School, University of Indonesia, Jakarta, Indonesia.

Reprint request to: Bernie Endyarni, MD, Department of Child Health, Medical School, University of Indonesia, Cipto Mangunkusumo Hospital, Jakarta, Indonesia. Tel. 62-21-3907742. Fax. 62-21-3907743. 
choice of measurement in monitoring the treatment of diabetes and metabolic control. ${ }^{1-7}$ In the diabetes control and complications trial (DCCT), improvement in metabolic control with intensification of diabetes management showed a decrease about $2 \%$ of $\mathrm{HbA} 1 \mathrm{c}$ level resulted in a significant reduced risk and progression of long-term complications by $27-76 \% .4,10$ 12 An addition of behavioral educational intervention to intensive diabetes management resulted in improved metabolic control and quality of life. ${ }^{10,12}$ Studies done by Hoey ${ }^{13}$ and Bauman ${ }^{14}$ show that adolescents with better metabolic control have better quality of life. Meanwhile, Kaplan ${ }^{15}$ and Lockington ${ }^{16}$ in their studies show that changes in knowledge of diabetic patients are not significantly associated with lowered $\mathrm{HbA} 1 \mathrm{c}$. A randomized control trial by Bloomgarden et $a^{17}$ found that patient education may not be an efficacious therapeutic intervention in most of type-1 diabetes patients since it can only increase patient knowledge but showed no significant decrease of HbAlc.

We conducted this study to analyze the effects of a structured educational intervention on metabolic control of type-1 diabetic patients in Department of Child Health, Medical School, University of Indonesia.

\section{Methods}

This prospective interventional study with pretestposttest design was conducted at Division of Endocrinology, Department of Child Health, Medical School, University of Indonesia, Cipto Mangunkusumo Hospital from June to November 2005. A total of 21 type-1 diabetic patients with the age between 8 and 18 years were included in the study and baseline data was collected at initial month. All patients and their parents were assigned to follow a structured educational program over period of 6 months. Their diabetes-related knowledge was assessed before and after education. The structured educational program used in this study consisted of 6 intervention sessions using combination of classroom teaching program, small group discussions, and role playing method which presented diabetesrelated education and management. We analyzed $\mathrm{HbAlc}$ at initial, $3^{\text {rd }}$ and $6^{\text {th }}$ month using high-performance liquid chromatography (HPLC) procedure with expected HbA1c level $<7 \%$. We used t-test, correlation and regression to determine association between level of $\mathrm{HbA1c}$, and knowledge of patients and parents; $\mathrm{P}$ value of $<0.05$ was considered significant. All analyses were carried out by using SPSS for Windows v.12.

\section{Results}

Of the 24 patients who were considered eligible, two of them refused to join the study. One patient was lost to follow-up due to moving out of Jakarta. A total of 21 patients were included with male: female ratio of 8:13. This was similar to study by Batubara, ${ }^{7}$ with ratio of 10:14. The age ranged from 8 to 17 years, with only 3 out of 21 patients were older than 15 years and educational level varied from elementary to high school. The age of diabetes onset ranged from 3.5 to 14 years with the most frequent age of onset was at age of 11 years. There were 9 of 21 patients whose diabetes had been diagnosed for at least 5 years, about half of patients were considered undernourished and one-third of patients had family history of diabetes. Baseline data of the 21 diabetic patients who eventually completed sufficient data are presented in Table 1.

Table 1. Baseline demographic characteristics of patients

\begin{tabular}{lc}
\hline Sex & \\
Male & 8 \\
Female & 13 \\
Age (years) & 12.6 (SD 2.67) \\
$8-12$ years & 9 \\
$>12-15$ years & 9 \\
$>15-18$ years & 3 \\
Educational levels & \\
$\quad$ Middle school or lower & 19 \\
$\quad$ High school & 2 \\
Duration of diabetes & \\
$\quad$ < year & 5 \\
1-5 years & 7 \\
$5-10$ years & 9 \\
Family status & \\
Pre-prosperous family & 1 \\
$>$ prosperous family & 20 \\
Parents lived at home & \\
Both parents & 19 \\
Single parent & 2 \\
Nutritional status & \\
Overweight & 2 \\
Wellnourished & 9 \\
Undernourished & 10 \\
Family history of diabetes & \\
Yes & \\
No &
\end{tabular}

Data are means SD or $\mathrm{n}$. 
Table 2. Clinical data for the 21 patients With complete follow-up at BASELINE AND AFTER 6 MONTHS.

\begin{tabular}{|c|c|c|}
\hline & Baseline & $6^{\text {th }}$ mo follow-up \\
\hline Daily insulin dosage (IU/kg/day) & 0.95 (SD 0.334) & 0.97 (SD 0.327) \\
\hline \multicolumn{3}{|l|}{ Insulin injection per day } \\
\hline 1x/day & 0 & 1 \\
\hline 2x/day & 21 & 20 \\
\hline \multicolumn{3}{|l|}{ Blood glucose measurement per day } \\
\hline Only at certain time* & 12 & 12 \\
\hline$<2 x /$ day & 9 & 9 \\
\hline Diabetic ketoacidosis & $2^{\star *}$ & 1 \\
\hline $\begin{array}{l}\text { Patients' diabetes-related knowledge } \\
(\% \text { correct answers }) \dagger\end{array}$ & 67.4 (SD 14.3) & $82.3(\mathrm{SD} 10.1)$ \\
\hline $\begin{array}{l}\text { Parents' diabetes-related knowledge } \\
\text { (\% correct answers) } ¥\end{array}$ & 68.7 (SD 13.2) & 84.4 (SD 8.7) \\
\hline HbA1c (\%)ף & $10.1(\mathrm{SD} 2.7)$ & $10.0(\mathrm{SD} 2.7)$ \\
\hline
\end{tabular}

Data are means $\pm S D$ or $n$. *When patient felt hypoglycemia or before visiting doctor.

** Within 6 months prior to study.

† $\mathrm{P}=0.000$ by t-test for the difference between patients' pre-posttests.

$\ddagger \mathrm{P}=0.000$ by t-test for the difference between parents' pre-posttests.

If $P>0.05$ by t-test.

Table 2 shows that daily insulin dosage, number of insulin injections and blood glucose tests per day remained relatively unchanged over the study period. During the study, there was only one patient who received a number of insulin injection adjustment from twice to once daily due to frequent hypoglycemia episodes. The mean $\mathrm{HbA1c}$ level in the 21 children and adolescents at initial, $3^{\text {rd }}$ and $6^{\text {th }}$ month were $10.05 \%$ (SD 2.67\%), 10.28\% (SD 2.23\%) and 10.01\% (SD $2.67 \%)$, respectively, which showed no significant changes $(\mathrm{P}>0.05)$ using t-test. The mean HbA1c of all patients during the study was $10.11 \%$ (SD 2.37\%). After 6 educational sessions, the results showed significant changes in both of parents' $(\mathrm{P}<0.05)$ and patients' knowledge $(\mathrm{P}<0.05)$.

In this study, as shown in Table 3, a higher mean $\mathrm{HbAlc}$ was found in male patients than that in female patients. Higher mean $\mathrm{HbAlc}$ was also found in patients who were living with both of their parents than single parent, but with uneven comparison of number of subjects. The mean $\mathrm{HbA1c}$ of age $>12-15$ years was the highest among other age groups. $\mathrm{Pa}$ tients in the longest duration of diabetes group had a higher $\mathrm{HbA1c}$ than those of shorter one. There was no association between numbers of attendance of patient in educational session and mean $\mathrm{HbA1c}$.

Figure 1 shows that there was a moderate significant negative correlation between patients' diabetes-related knowledge with mean $\mathrm{HbA1c}(\mathrm{r}=$ 0.632; $\mathrm{P}=0.02$ ). A significant correlation can also be seen between patients' diabetes-related knowledge with patients' $\mathrm{HbA1c}$ level at $6^{\text {th }}$ month $(\mathrm{r}=-0.6$; $\mathrm{P}=0.04)$. However, in our study, there was no significant correlation between parents' diabetes-related knowledge with patients' $6^{\text {th }}$ month $\mathrm{HbA1c}(\mathrm{r}=$ $0.314 ; \mathrm{P}=0.166)$ and with mean HbA1c $(\mathrm{r}=-0.348$;

Table 3. Comparison of mean HbA1c measurements DURING THE STUDY PERIOD ACCORDING TO DEMOGRAPHIC AND CLINICAL CHARACTERISTICS OF PATIENTS

\begin{tabular}{|c|c|c|}
\hline & $\mathbf{n}$ & Mean HbA1c (\%) \\
\hline \multicolumn{3}{|l|}{ Sex } \\
\hline Male & 8 & 11.2 (SD 2.9) \\
\hline Female & 13 & $9.4(\mathrm{SD} 1.8)$ \\
\hline \multicolumn{3}{|l|}{ Age } \\
\hline 8-12 years & 9 & 9.7 (SD 2.3) \\
\hline$>12-15$ years & 9 & 10.6 (SD 2.8) \\
\hline$>15$ years & 3 & $9.6 \pm 1.19$ \\
\hline \multicolumn{3}{|l|}{ Duration of diabetes } \\
\hline$<1$ year & 5 & $8.55 \pm 1.95$ \\
\hline $1-5$ years & 7 & $10.27 \pm 1.57$ \\
\hline >5-10 years & 9 & $10.86+2.85$ \\
\hline \multicolumn{3}{|l|}{ Parents lived at home } \\
\hline Both parents & 19 & $10.2+2.47$ \\
\hline Single parent & 2 & $9.24+0.72$ \\
\hline \multicolumn{3}{|c|}{ According to total attendance } \\
\hline $2 x$ & 1 & 10.7 \\
\hline $3 x$ & 5 & $8.45+2.38$ \\
\hline $4 x$ & 7 & $11.37 \pm 2.87$ \\
\hline $5 x$ & 7 & $9.93 \pm 1.57$ \\
\hline $6 x$ & 1 & 10.23 \\
\hline \multicolumn{3}{|c|}{ Blood glucose measurement per day } \\
\hline Only at certain time* & 12 & $10.32+2.60$ \\
\hline$<2 x /$ day & 9 & $9.84 \pm 2.14$ \\
\hline
\end{tabular}




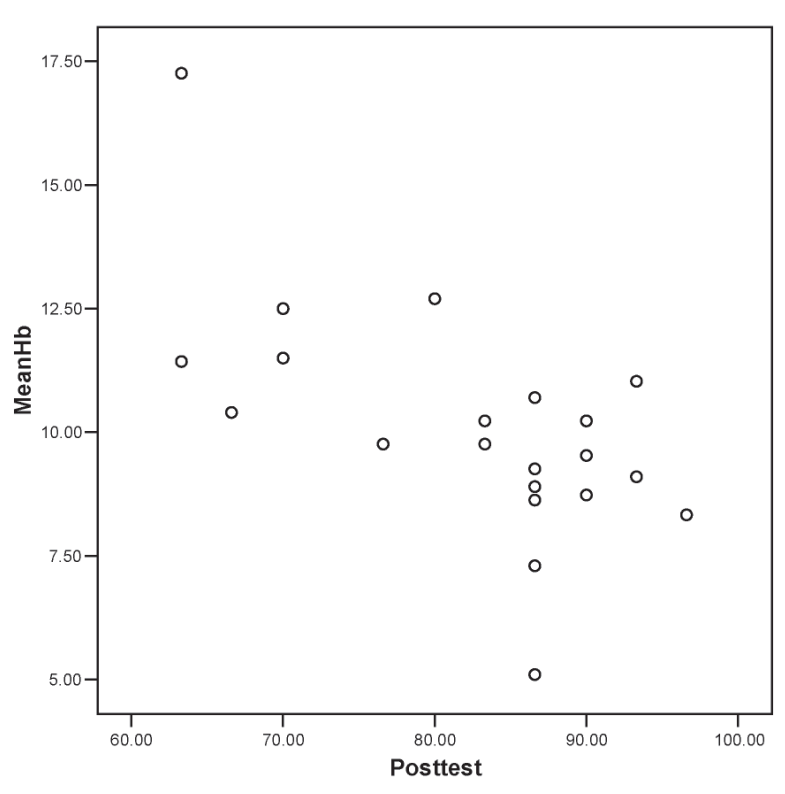

Figure 1. Correlation between results of patients' POST-TEST AND MEAN HBA1C.

$\mathrm{P}=0.122$ ), even though it was clearly described that subjects with better parents' diabetes-related knowledge tended to have lower HbA1c level.

\section{Discussion}

Among other chronic health conditions, diabetes is unique since the majority of the treatment depends on self-management. Therefore, diabetes-related education is crucial to the treatment and management of the disease. ${ }^{18-19}$ Our study demonstrated the beneficial effects of a structured educational intervention on overall patients and parents knowledge as well as its correlation with metabolic control. After a 6-month educational intervention, we found a significant increase in patients' and parents' diabetes-related knowledge $(\mathrm{P}<0.05)$.

In our patients, higher scores of patient diabetes-related knowledge were significantly correlated with lower HbA1c levels, underlining the positive effect of patient education. Parents' diabetes-related knowledge also showed a correlation with $\mathrm{HbA1c}$, but they were not significantly correlated based on t-test. Since most of our patients were adolescents, this result confirmed that many adolescents managed their diabetic treatment by themselves. Meanwhile, parents play more important roles in diabetic management of younger children.

From previous observations, it is known that only very few patients were able to achieve or maintain normal HbA1c levels. ${ }^{15-17,20}$ In present study, number of patients whose $\mathrm{HbA} 1 \mathrm{c}$ level $<8 \%$ at initial and end of study was only 4 of 21 patients consisted of different patients. This condition is similar with study by Batubara ${ }^{6}$ in 7 pediatric diabetes centers in Indonesia that showed $90 \%$ and $85 \%$ of patients had $\mathrm{HbA} 1 \mathrm{c}>7.5 \%$ and $>8 \%$ respectively. Cardwell ${ }^{21}$ reported that in Northern Ireland about $80 \%$ of patients had $\mathrm{HbAlc}>7.5 \%$.

The three times measurements and the overall mean of $\mathrm{HbA1c}$ level of our patients during the study remained relatively unchanged which were all $>10 \%$. Batubara ${ }^{6,7}$ reported similar result of 10.5 (SD2.7\%) and $10.6 \%$. Meanwhile, Cardwell ${ }^{21}$ showed a lower $\mathrm{HbA1c}$ level which was $8.8 \%$. These findings showed that metabolic control in our patients before and after educational intervention was still poor. However, there are other confounding factors that also take part in influencing $\mathrm{HbAlc}$ besides education and knowledge of patient.

According to sex distribution there was a slight female predominance (13/21 vs. 8/21) which was similar to study by Batubara ${ }^{7}$ at the same hospital (14/24 vs. 10/24). In our study, male patients showed a higher $\mathrm{HbA1c}$ level than that of female patients. Other studies differed from ours; Dorchy ${ }^{22}$ stated that $\mathrm{HbA1c}$ was not related to sex while Hoey ${ }^{13}$ reported that female patients had higher HbA1c level than males. The differences in these studies are caused by differences in population, race and number of subjects of study.

The present results showed that patients in age group of $>12-15$ years had the highest $\mathrm{HbA1c}$ level during the study period. This is in accordance with most studies that showed higher $\mathrm{HbAlc}$ during puberty. ${ }^{2-5,9,21}$ Even though successful metabolic control in young patients depends mainly on the quality and intensity of diabetes education, ${ }^{11,12,22}$ there are other influencing factors that play important roles in adolescents; decrease of compliance, ${ }^{23,22}$ peer group, ${ }^{9}$ hormones, ${ }^{5}$ stress, changes in diet, and behaviour. ${ }^{23}$

With regard to the duration of diabetes, we found that level of $\mathrm{HbA1c}$ patients with longer duration of diabetes was higher than that with shorter duration 
of diabetes $(\mathrm{P}>0.05)$. This result was similar with Dorchy $^{22}$ who reported that after 2 years of diabetes, the level of HbA1c was higher. This fact is due to lower frequency of home blood glucose monitoring and visiting doctors.

The proportion of patients reporting $<2 \mathrm{x}$ blood glucose measurements daily remained unchanged. These patients had lower HbAlc than those who performed only at certain times $(\mathrm{P}>0.05)$. This result is in accordance to study by Haller ${ }^{24}$ who reported that increase in blood glucose measurement was associated with decrease in HbA1c. ${ }^{11}$

Although our present study clearly showed a significant correlation between patients' diabetes-related knowledge and level of $\mathrm{HbAlc}$, we have to admit that there are other confounding factors which played important roles in determining patient's metabolic control.

In conclusion, our study confirmed that a structured educational intervention is able to improve patients' and parents' diabetes-related knowledge significantly. Moreover, patients' diabetes-related knowledge has a significant negative correlation while parents' diabetes-related knowledge has no significant correlation with patient $\mathrm{HbA1c}$ level. A future research to find the most influencing factors to metabolic control would be useful.

\section{References}

1. The expert committee on the diagnosis and classification of diabetes mellitus. Report of the Expert Committee on the Diagnosis and Classification of Diabetes Mellitus. Diabetes care 2001;24:S5-18.

2. Laron Z, Karp M. Diabetes mellitus in children and adolescents. In: Bertrand J, Rappaport R, Sizonenko P, editors. Pediatric endocrinology: Physiology, pathophysiology, and clinical aspects. 2nd ed. Baltimore: Williams \& Wilkins; 1993. p. 597-617.

3. Batubara JRL. Penatalaksanaan diabetes pada anak. In: Pusat diabetes dan lipid RSUPNCM FKUI. Penatalaksanaan diabetes melitus terpadu. 1st ed. Jakarta: Aksara Buana; 1999. p. 149-56.

4. UKK Endokrinologi. Konsensus nasional pengelolaan diabetes melitus tipe-1 di Indonesia. Jakarta; 2000. p. 5-45.

5. Sperling MA. Diabetes mellitus in children. In: Behrman RE, Kliegman RM, Jenson HB, editors.
Nelson textbook of pediatrics. 16th ed. Philadelphia: W.B. Saunders; 2000. p. 1767-86.

6. Batubara JRL. Audit of childhood diabetes control in Indonesia. Paediatr Indones 2002;42:280-6.

7. Batubara JRL, Firmansyah A, Mansyoer R, Tridjaja B, Pulungan AB. Clinical and laboratory features of children with insulin dependent diabetes mellitus of more than two years. Paediatr Indones 2001;41:255-9.

8. Allen C, LeCaire T, Palta M, Daniels K, Meredith M, D'Alessio DJ. Risk factors for frequent and severe hypoglycemia in type 1 diabetes. Diabetes care 2001; 24:1878-81.

9. Silverstein J, Klingensmith G, Copeland K, Plotnick L, Kaufman F, Laffel L, et al. Care of children and adolescents with type 1 diabetes, a statement of the American Diabetes Association. Diabetes care 2005;28:186-212.

10. American diabetes association. Standards of medical care for patients with diabetes mellitus. Diabetes care 2001;24:S33-43.

11. The diabetes control and complications trial (DCCT) research group. The effect of intensive treatment of diabetes on the development and progression of long-term complications in insulin-dependent diabetes mellitus. N Engl J Med 1993; 329:977-86.

12. Grey M, Boland EA, Davidson M, Li J, Tamborlane WV. Coping skills training for youth with diabetes mellitus has long-lasting effects on metabolic control and quality of life. J Pediatr 2000;137:107-13.

13. Hoey H, Aanstoot HJ, Chiarelli F, Daneman D, Danne $\mathrm{T}$, Dorchy $\mathrm{H}$, et al. Good metabolic control is associated with better quality of life in 2,101 adolescents with type 1 diabetes. Diabetes care 2001;24:1923-8.

14. Bauman IG, Strugger M, Flaherty BP, McEvoy RC. Metabolic control and quality-of-life self-assessment in adolescents with IDDM. Diabetes care 1998;21:915-8.

15. Kaplan RM, Chadwick MW, Schimmel LE. Social learning intervention to promote metabolic control in type I diabetes mellitus: Pilot experiment results. Diabetes care 1985;8:152-5.

16. Lockington TJ, Powles S, Meadows KA, Wise PH. Attitudes, knowledge and blood glucose control. Diabet Med 1989;6:309-13.

17. Bloomgarden ZT, Karmally W, Metzger MJ, Brothers M, Nechemias C, Bookman J, et al. Randomized, controlled trial of diabetic patient education: Improved knowledge without improved metabolic status. Diabetes care 1987;10:263-72. 
18. LeBlanc LA, Goldsmith T, Patel DR. Behavioral aspects of chronic illness in children and adolescents. Pediatr Clin North Am 2003;50.

19. Schumacher EP, Jacksonville S. Diabetes self-management education: The key to living well with diabetes. Cited 2005 April 7. Available from: http://www.dcmsonline.org/lax-medicine/2005 journals /Diabetes/diab05j-pt-education.pdf.

20. Pieber TR, Brunner GA, Schnedi WJ, Schattenberg S, Kaufmann P, Krejs GJ. Evaluation of a structured outpatient group education program for intensive insulin therapy. Diabetes care 1995;18:625-30.

21. Cardwell CR, Patterson CC, Allen M, Carson DJ. Diabetes care provision and glycaemic control in North- ern Ireland: A UK regional audit. Arch Dis Child 2005;9:468-73.

22. Dorchy H, Roggemans MP, Willems D. Glycated hemoglobin and related factors in diabetic children and adolescents under 18 years of age: A Belgian experience. Diabetes care 1997;20:2-6.

23. Mendez FJ, Belendez M. Effects of a behavioral intervention on treatment adherence and stress management in adolescents with IDDM. Diabetes care 1997;20(9):1370-5.

24. Haller MJ, Stalvey MS, Silverstein JH. Predictors of control of diabetes: Monitoring may be the key. J Pediatr 2004;144:660-1. 